ORIGINAL ARTICLE

\title{
Effect of follicle size on oocytes recovery rate, quality, and in-vitro developmental competence in Bos indicus cows
}

\author{
Zaeem Sarwar ${ }^{1,2}$ (D), Muhammad Saad ${ }^{1,2}$ (D), Muhammad Saleem ${ }^{1}$ (D), Ali Husnain ${ }^{1,3}$ (D), Amjad Riaz ${ }^{1}$, \\ Nasim Ahmad',3* (D) \\ ${ }^{1}$ Department of Theriogenology, Faculty of Veterinary Science, University of Veterinary and Animal Sciences, Lahore, Pakistan \\ ${ }^{2}$ Department of Theriogenology, Faculty of Veterinary Science, Cholistan University of Veterinary and Animal Sciences, \\ Bahawalpur, Pakistan \\ ${ }^{3}$ Department of Animal Sciences, University of Florida, Gainesville, FL, United States
}

How to cite: Sarwar Z, Saad M, Saleem M, Husnain A, Riaz A, Ahmad N. Effect of follicle size on oocytes recovery rate, quality, and in-vitro developmental competence in Bos indicus cows. Anim Reprod. 2020;17(3):e20200011. https://doi.org/10.1590/1984-3143-AR2020-0011

\begin{abstract}
The objective of the present study was to determine the effect of follicle size on recovery rate, quality, and in-vitro developmental competence of oocytes in Bos indicus cows. The ovaries ( $n=507)$ of Bos indicus cows having age of 5-8 years, with mixed parity, BCS $2.75 \pm 0.25$, and clinically normal reproductive tracts were collected from the local abattoir. The follicles on the ovaries were divided into two groups based upon their size; 1 ) $\geq 6 \mathrm{~mm}$ diameter, and 2) $<6 \mathrm{~mm}$ diameter. After initial evaluation of quality of the oocytes, the COCs were in vitro matured, fertilized, and cultured to determine the in vitro developmental competence. The oocyte recovery, quality, maturation, cleavage, 4-cell, 8-cell, and 16-cell stages were analyzed using PROC GLIMMIX procedure of SAS. However, the number of oocytes recovered per ovary was analyzed using MIXED procedure of SAS. Results revealed that the recovery of oocytes ( $L S M \pm S E M)$ derived from the follicles having size $<6 \mathrm{~mm}$ per ovary was greater (1.02 vs. $3.14 \pm 0.13 ; P<0.0001)$. However, the percentage $(\mathrm{n} / \mathrm{n})$ recovery [69.8 (474/679) vs. 62.7\% (1454/2320); $P=0.01]$ and grade I_+_ll oocytes [68.4 (324/474) vs. 57.9\% (842/1454); $P<0.0001$ ] was greater in $\geq 6 \mathrm{~mm}$ as compared with $<6 \mathrm{~mm}$ group, respectively. However, maturation rate did not differ [92.9 (288/310) vs. $92.2 \%(296 / 321) ; P=0.98]$ between the groups. In contrast, cleavage rate [58.1 (180/310) vs. 47.4\% (152/321); $P=0.01$ ], the 4-cell [34.5 (107/310) vs. $18.7 \%(60 / 321) ; P=0.0003]$, 8-cell [15.5 (48/310) vs. $7.8 \%(25 / 321) ; P=0.008]$, and 16-cell [8.7 (27/310) vs. $2.1 \%(7 / 321) ; P=0.004$ ] stage embryos were greater in $\geq 6 \mathrm{~mm}$ group. It can be concluded that oocytes derived from follicle $\geq 6 \mathrm{~mm}$ have better in vitro developmental competence based on embryonic conversion in Bos indicus cows.
\end{abstract}

Keywords: Size of follicle, in-vitro developmental competence, Bos indicus cows.

\section{Introduction}

Assisted reproductive technologies (ART) have revolutionized the dairy industry in the past century for the rapid multiplication and up gradation of the superior genetics (Moore and Hasler, 2017). However, genetic exploitation through in-vitro embryo production (IVEP) in the farm animals remained challenging during the last three decades (Thompson, 1997) The IVEP involves oocyte collection, maturation, sperm capacitation, fertilization, and embryo culture (Rose and Bavister, 1992). Several factors influence the outcome of IVEP technique which include, oocytes obtained either from slaughtered or live animal (Gasparrini, 2002), parity (Snijders et al., 2000a), age (Armstrong, 2001), stage of the estrous cycle (De Wit et al., 2000), blood progesterone concentration (Saad et al., 2019), body condition score (BCS), milk

*Corresponding author: nasimahmad@uvas.edu.pk

Received: February 20, 2020. Accepted: August 19, 2020

Financial Support: This research was financially supported by NRPU project of Higher Education Commission (HEC), Islamabad, Pakistan (Project no 20-4259) Conflict of interest: nothing to declare. 
production (Snijders et al., 2000b), season of the year (Al-Katanani et al., 2002), cyclicity (Boediono et al., 1995), capacitation method (Parrish et al., 1995), sex preselection of embryos (Chowdhury et al., 2019) and size of the follicle (Pavlok et al., 1992; Lonergan et al., 1994). These factors are in addition to the laboratory procedures (Gordon, 2003) which are the key determinants for the success of IVEP technique.

Under in vivo conditions about 85\% embryos were developed from the spontaneously ovulated oocytes in normal cyclic cows (Montalenti, 1968). In contrast, during IVEP only about 20-40\% transferable embryos were produced from oocytes derived from slaughterhouse ovaries or ovum pick up (Pavlok et al., 1992; Lonergan et al., 1994; Otoi et al., 1997; Lequarre et al., 2005; Camargo et al., 2018). The difference is because oocytes resuming meiosis in vivo, originate from the follicles having size $>15 \mathrm{~mm}$. Moreover, in vivo derived oocytes mature in approximately five days and achieve a size of $>15 \mathrm{~mm}$ (Driancourt, 1991). Contrarily, the oocytes for in vitro studies are derived from different sized follicles varying from 2-15 $\mathrm{mm}$ and matured only for 24 hours. Due to which the meiosis resumption abilities of oocytes varies in vitro (Pavlok et al., 1992; Lonergan et al., 1994; Otoi et al., 1997; Lequarre et al., 2005; Caixeta et al., 2009) Furthermore, the capabilities of the oocytes to fertilize and grow in vitro up to advanced embryonic stages have been known to be dependent upon the size of follicle from which oocytes were retrieved. The oocytes recovered from $\geq 6 \mathrm{~mm}$ follicles were better in terms of quality and in vitro developmental competence (Pavlok et al., 1992; Lonergan et al., 1994) Variations in the size of follicle lead to the difference in the in vitro developmental competencies of the oocytes (Hendriksen et al., 2000). Thus, the size of the follicles from which the oocytes are retrieved is a key factor to determine IVEP rates along with other factors (Pavlok et al., 1992; Lonergan et al., 1994; Crozet et al., 1995; Caixeta et al., 2009). The mechanism why blastocyst yield is lower in small follicles is because they have delayed cavitation and retorted growth stages of cell cycle (Lequarre et al., 2005). Therefore, we hypothesized that oocytes recovery, quality and in vitro developmental competence in $\geq 6 \mathrm{~mm}$ sized follicles will be better than the $<6 \mathrm{~mm}$ sized follicles in Bos indicus cows.

Bos indicus cattle are best known for heat tolerance and tick resistance in tropical and subtropical regions (Glass et al., 2005; Khan et al., 2008). The reproductive physiology of Bos taurus is quite different from Bos indicus cows (Sartori et al., 2010). Bos indicus cows require longer times to attain puberty, have prolonged postpartum anestrus duration, shows greater tendency of seasonal breeding, and displays a shorter duration of estrus with fewer overt signs (Bó et al., 2003). Most of the work on ART has been conducted in Bos taurus. Similar information is generally lacking in Bos indicus cows. It was hypothesized that for the oocytes recovered from the follicles having size $\geq 6 \mathrm{~mm}$ will have greater recovery rate, oocytes quality as well as an early in vitro developmental competence as compared to the oocytes derived from $<6 \mathrm{~mm}$ follicles. Therefore, the objective of the present study was to determine the effect of follicle size on recovery rate, quality, in-vitro developmental competence of oocytes based on embryonic conversion in Bos indicus cows.

\section{Materials and methods}

This study was conducted during 2018 in the embryology laboratory of the University of Veterinary and Animal Sciences, Ravi Campus, Pattoki, Punjab-Pakistan. The research was approved by the Ethical Review Committee of UVAS, Lahore (Reference No. DR/178). All the experiments were performed using the commercially available IVF media (Minitüb GmbH, Germany) and all the reagents of Sigma Chemical Company (St. Louis, MO, USA).

\section{Collection of oocytes and experimental design}

The Bos indicus ovaries $(n=507)$ were collected from slaughtered cows having 5 - 8 years of age and mixed parity, with clinically normal reproductive tracts. The ovaries were brought to laboratory in solution containing $0.9 \%$ sodium chloride solution (Sigma; cat \# S5886), added with $50 \mathrm{mg} / \mathrm{ml}$ streptomycin (Sigma; cat \# P4562) and $500 \mu \mathrm{g} / \mathrm{ml}$ penicillin (Sigma; cat \# P3032) and maintained at 
temperature of $30-35^{\circ} \mathrm{C}$ within 2 hours after slaughtering. Later, in the laboratory, the ovaries were washed three times with normal saline in to minimize the contamination.

The follicles were classified based upon their size into two groups: 1) $\geq 6 \mathrm{~mm}$, and 2) $<6 \mathrm{~mm}$ as classified by (Lonergan et al., 1994). Afterwards, oocytes were aspirated with $18 \mathrm{G}$ needle and $10 \mathrm{ml}$ syringe by ovum pick up media (Minitüb $\mathrm{GmbH}$, Germany). The cumulus-oocyte complexes (COCs) were categorized into four classes based on the number of COCs layers and cytoplasmic aspects (Kastrop et al., 1990). Only Grade I_+_ll oocytes were selected for advanced processing. Thereafter, COCs were washed three times in TL HEPES solution (Minitüb GmbH, Germany) supplemented with $6 \mathrm{mg} / \mathrm{ml}$ bovine serum albumin (BSA; Sigma fraction V, cat \# A6003).

\section{In vitro maturation (IVM)}

Oocytes were washed three times in IVM medium consisting of (TCM 199 stock solution; Minitüb $\mathrm{GmbH}$, Germany) added with estrus cow serum (OCS, own produced and deactivated), $0.5 \mu \mathrm{g} / \mathrm{ml}$, follicle stimulating hormone (FSH; Sigma; cat \# F2293) and $0.25 \mu \mathrm{g} / \mathrm{ml}$, luteinizing hormone (LH; Sigma; cat \# L5269). All COCs of the two groups ( $\geq 6 \mathrm{~mm}$ vs. $<6 \mathrm{~mm}$ ) were placed in separate $100 \mu$ I IVM drops in four well plates (SPL Life Sciences, Korea) covered with a pre-warmed mineral oil layer (SigmaM5310). Four well plates were incubated for a period of 24 hours in $\mathrm{CO}_{2}$ incubator (Shel lab; 3503-2, USA) with $5 \% \mathrm{CO}_{2}$ and with maximum humidity at $38.5^{\circ} \mathrm{C}$. After 24 hours, IVM was evaluated based on degree of expansion of the COC layers and on the success of extrusion of the first polar body (Pavlok et al., 1992).

\section{In vitro fertilization (IVF)}

After the IVM, the COCs were washed three times in the drops of IVF media consisted of TL stock solution (Minitüb GmbH, Germany) supplemented with BSA $(6 \mathrm{mg} / \mathrm{ml})$, sodium-pyruvate (Sigma; cat \# $\mathrm{P} 4562 ; 10 \mu \mathrm{l} / \mathrm{ml}$ ), and heparin (Sigma; cat\# H3149; $20 \mu \mathrm{l} / \mathrm{ml}$ ). After washing, COCs were placed in 100 $\mathrm{ll}$ IVF media droplets covered with pre warmed mineral oil (Sigma-M5310). The capacitated semen ( $50 \mu \mathrm{l} / \mathrm{drop}$ ) was added into the IVF drops and four well plates were incubated for a time period of 18 hours at $38.5^{\circ} \mathrm{C}, 5 \% \mathrm{CO}_{2}$ along with maximum relative humidity.

For in vitro capacitation of the sperms two straws of progeny tested Sahiwal bull (Bos indicus) having the same batch and of known fertility were pooled into the falcon tube. The semen having $>40 \%$ post thaw motility was placed at the bottom of capacitation media. This media comprised of TL stock solution (Minitüb GmbH, Germany) supplemented with BSA ( $6 \mathrm{mg} / \mathrm{ml}$ ), $50 \mu \mathrm{l} / \mathrm{ml}$ sodium-pyruvate (Sigma; cat \# P4562), and $1 \mu \mathrm{l} / \mathrm{ml}$ gentamicin (Sigma; cat \# 345815). Thereafter, the falcon tube was incubated at $38.5^{\circ} \mathrm{C}$ for 30 minutes in tilted form. Furthermore, motile sperms from supernatant were transferred and centrifuged at $328 \mathrm{~g}$ for 10 minutes in another sterile falcon tube as described earlier (Pavlok et al., 1992). After discarding supernatant, the remaining pellet was mixed gently with capacitation media to make the final concentration of 2 million sperms per $\mathrm{ml}$.

After 18 hours, fertilization was evaluated based on presence of male and female pronuclei or cleavage (Lonergan et al., 1994).

\section{In vitro culture (IVC)}

After fertilization evaluation, the presumptive zygotes were washed three times in media containing TL HEPES (Minitüb GmbH, Germany) solution supplemented with BSA (6 mg/ml). Meanwhile, denuding of zygotes was performed with gentle pipetting. Subsequently, presumptive zygotes were washed thrice in IVC media droplets composed of SOF stock solution (Minitüb GmbH, Germany) supplemented with $1 \mathrm{ml}$ estrus cow serum (own produced and deactivated), $40 \mu \mathrm{l} / \mathrm{ml}$ amino acids essential (Sigma; cat \# M5550), and $10 \mu \mathrm{l} / \mathrm{ml}$ amino acids non-essential (Sigma; cat \# M7145). After washing, the presumptive zygotes were placed in pre-warmed 100 $\mathrm{ll}$ IVC droplets, overlaid with mineral oil at $38.5^{\circ} \mathrm{C}, 5 \% \mathrm{CO} 2$ and $95 \%$ relative humidity. To check every cell stage, In vitro embryonic development was recorded on days $3,4,5$, and 6 after the day of insemination. 


\section{Statistical analysis}

Continuous response variable that is the mean number of oocytes recovered per ovary from follicles having size $\geq 6 \mathrm{~mm}$ and $<6 \mathrm{~mm}$ was analyzed by using the MIXED procedure of SAS (SAS ver. 9.4 Institute, Inc., Cary, NC, USA). The proportion of the oocytes recovered per follicle, oocyte quality, maturation, cleavage, embryo development to the 4-cell, 8-cell, and 16 cell stages when oocytes were derived from either $\geq 6 \mathrm{~mm}$ and $<6 \mathrm{~mm}$ oocytes were analyzed using the PROC GLIMMIX procedure of SAS (SAS ver. 9.4 Institute, Inc., Cary, NC, USA). The data were of binominal distribution. All models included the fixed effect of follicle size and the random effect of replicate (day of collection of ovaries). The contemporary group on a specific slaughter day was considered as the experimental unit. The level of significance to reject the null hypotheses $(\mathrm{HO})$ was $5 \%$, and values for a variable were different when $P \leq 0.05$.

\section{Results}

Effect of follicle size on the percent oocytes recovery, quality of oocytes and in vitro developmental competence of the embryos in Bos indicus cows has been presented in the Table 1. The odds of recovery of oocytes for follicle $\geq 6 \mathrm{~mm}$ was $28 \%$ greater (Odds ratio; $1.28,95 \% \mathrm{Cl} ; 1.06-1.56, P=0.01$ ) than the odds for follicle $<6 \mathrm{~mm}$. The percentage of grade I_+_Il oocytes was greater [68.4 (324/474) vs. 57.9\% (842/1454); $P<0.0001]$ and the oocytes with grade III_+_IV were lower [31.6 (150/474) vs. $57.9 \%$ (842/1454); $P<0.0001]$ between the oocytes recovered from the follicles having size $\geq 6 \mathrm{~mm}$ as compare with $<6 \mathrm{~mm}$. However, the maturation rate did not differ (Odds ratio; 1.01, 95\% Cl; 0.54-1.88, $P=0.98$ ) between the groups. The in-vitro developmental competence of oocytes revealed that the cleavage rate [58.1 (180/310) vs. $47.4 \%(152 / 321) ; P=0.01]$, 4-cell stage [34.5 (107/310) vs. $18.7 \%$ (60/321); $P=0.0003$ ] and 8-cell stage embryos [15.5 (48/310) vs. 7.8\% (25/321); $P=0.008$ ] were greater in the oocytes obtained from $\geq 6 \mathrm{~mm}$ sized follicles as compared with the oocytes recovered from $<6 \mathrm{~mm}$ follicle. Similarly, the 16-cell stage embryos were greater [8.7 (27/310) vs. 2.1\% (7/321); $P=0.004]$ in $\geq 6 \mathrm{~mm}$ group. Results revealed that oocytes recovered from follicles having size $\geq 6 \mathrm{~mm}$ have better recovery, quality and in vitro developmental competency based on embryonic conversion in Bos indicus cows.

Table 1. Percentage ( $n / n)$ along odds ratio with $95 \%$ confidence interval for the effect of follicle size on recovery, quality, and in-vitro developmental competence of oocytes in Bos indicus cows ${ }^{1}$.

\begin{tabular}{|c|c|c|c|c|c|c|}
\hline Variables & $\geq 6 \mathrm{~mm}$ & $<6 \mathrm{~mm}$ & $\begin{array}{l}\text { Odds } \\
\text { ratio }\end{array}$ & \multicolumn{2}{|c|}{$\begin{array}{c}95 \% \text { confidence } \\
\text { interval }\end{array}$} & P-value \\
\hline $\begin{array}{l}\text { Oocyte recovery per } \\
\text { follicle } ; \%\end{array}$ & $69.8(474 / 679)$ & $62.7(1454 / 2320)$ & 1.28 & 1.06 & 1.56 & 0.01 \\
\hline Grade I_+_II oocyte ${ }^{3} ; \%$ & $68.4(324 / 474)$ & $57.9(842 / 1454)$ & 3.04 & 2.40 & 3.85 & $<0.0001$ \\
\hline Grade III_+_IV oocyte $; \%$ & $31.6(150 / 474)$ & $57.9(842 / 1454)$ & 0.33 & 0.26 & 0.42 & $<0.0001$ \\
\hline Matured oocyte $; \%$ & $92.9(288 / 310)$ & $92.2(296 / 321)$ & 1.01 & 0.54 & 1.88 & 0.98 \\
\hline Cleavage $; \%$ & $58.1(180 / 310)$ & $47.4(152 / 321)$ & 1.54 & 1.1 & 2.15 & 0.01 \\
\hline 4-cell stage embryo7; \% & $34.5(107 / 310)$ & $18.7(60 / 321)$ & 2.29 & 1.54 & 3.39 & 0.0003 \\
\hline 8-cell stage embryo ${ }^{8} ; \%$ & $15.5(48 / 310)$ & $7.8(25 / 321)$ & 2.21 & 1.27 & 3.84 & 0.008 \\
\hline 16 -cell stage embryo $; \%$ & $8.7(27 / 310)$ & $2.1(7 / 321)$ & 4.14 & 1.77 & 10.30 & 0.004 \\
\hline
\end{tabular}

1 Oocytes were categorized based upon the size of follicle $\geq 6 \mathrm{~mm}$ or $<6 \mathrm{~mm}$. ${ }^{2}$ For odds ratio the reference was the oocyte derived from the size of follicle $<6 \mathrm{~mm}$. ${ }^{3} \mathrm{Grade}$ I_+_II oocyte; number of oocytes with grade I_+_II/ total number of oocytes recovered ${ }^{4}$. 100*Grade III_+_IV oocyte; number of oocytes with grade III_+_IV/ total number of oocytes recovered $^{5} .100^{*}$ Matured oocyte; number of oocytes matured/ total number of oocytes cultured for in vitro maturation ${ }^{6}$. 100*Cleavage; number of oocytes cleaved/ total number of oocytes cultured for in vitro maturation $100^{*}$. ${ }^{7} 4$-cell stage embryo; number of 4 -cell stage embryos/ total number of oocytes cultured ${ }^{8} 8$. 100*-cell stage embryo; number of 8 -cell stage embryos/ total number of oocytes cultured ${ }^{9} 16.100 *$-cell stage embryo; number of 16 -cell stage embryos/ total number of oocytes cultured100*.

Effect of size of follicle on oocytes recovered per ovary (LSM $\pm \mathrm{SEM}$ ) in Bos indicus cows is presented in Figure 1. Greater number of follicles having size $<6 \mathrm{~mm}$ were present per ovary in Bos indicus cows. Therefore, greater (1.02 vs. $3.14 \pm 0.13, P<0.0001)$ was the recovery of oocytes per ovary from follicles size $<6 \mathrm{~mm}$ as compared with $\geq 6 \mathrm{~mm}$ sized follicle. 


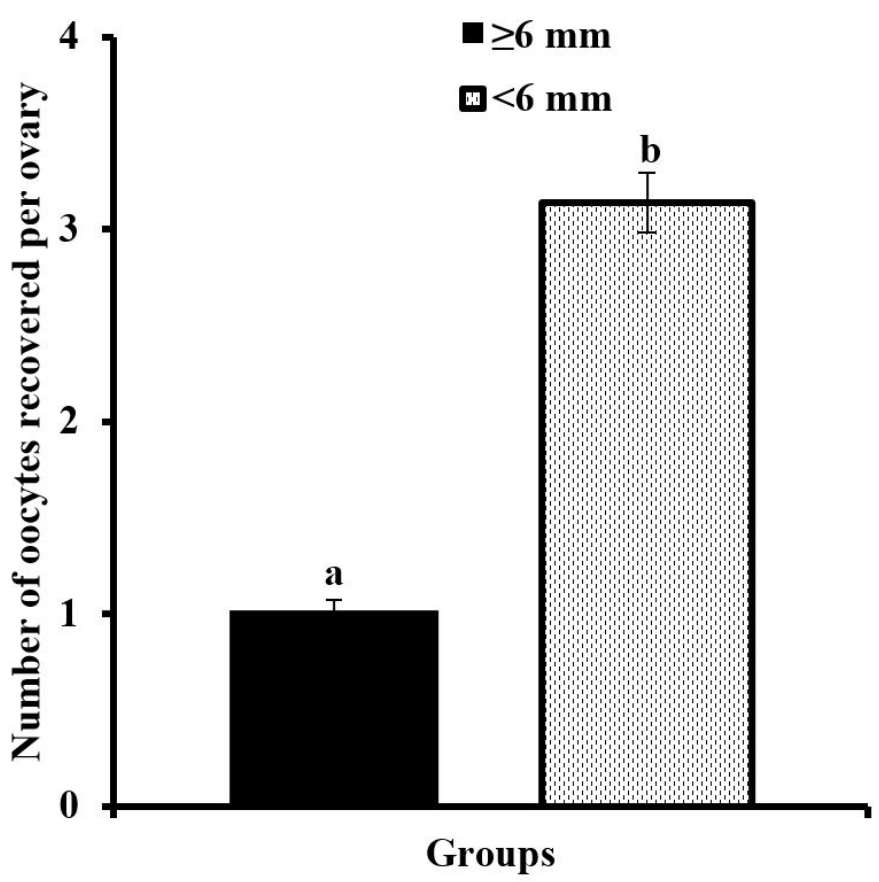

Figure 1. Effect of follicle size on number of oocytes recovered per ovary (least square mean $\pm \mathrm{SEM}$ ) from $\geq 6 \mathrm{~mm}$ and $<6 \mathrm{~mm}$ groups in Bos indicus cows. ${ }^{\mathrm{a}, \mathrm{b}}$ superscripts differ $(P<0.05)$ between both groups.

\section{Discussion}

Present study determines the effect of follicle size on the recovery rate, quality and in vitro developmental competence of oocytes in Bos indicus cows. We hypothesized that $\geq 6 \mathrm{~mm}$ follicles would have better recovery, quality, and in-vitro developmental competency of oocytes (Pavlok et al., 1992; Lonergan et al., 1994). In the present study, the most salient findings were manifested that the cleavage rate, number of 4-cell and 8-cell stage embryos were greater in the oocytes recovered from $\geq 6 \mathrm{~mm}$ (larger follicles) as compared with $<6 \mathrm{~mm}$ follicles (smaller follicles), respectively. Likewise, the 16 cell stage embryos (16-cell) were also greater from the oocytes retrieved from the large follicles. These findings are supported by the previous studies, in which the oocytes derived from $\geq 6 \mathrm{~mm}$ follicles for IVEP yielded better quality embryos in Bos taurus cows (Pavlok et al., 1992; Lonergan et al., 1994; Lequarre et al., 2005).

The most plausible reasons for the lower IVEP rates of oocytes derived from $<6 \mathrm{~mm}$ follicles includes incomplete nuclear and cytoplasmic maturation, greater degree of atresia, (Pavlok et al., 1988), and higher degree of fertilization abnormalities (Pavlok et al., 1988) than the oocytes derived from $\geq 6 \mathrm{~mm}$ follicles. Furthermore, the oocytes derived from $<6 \mathrm{~mm}$ follicles have inadequate synthesis of maternal mRNAs that are required for the compaction and differentiation of the embryos at advanced stages (Crozet et al., 1986; Shabankareh et al., 2015 and lack of production of essential proteins which are required for in vitro growth competence (Sirard et al., 1989). In addition, the previous studies had reported that the oocytes from small follicles have irregular cortical granules distribution, defective system of exocytosis, have greater fertilization abnormalities and thus not capable of supporting the embryonic development (Cran and Cheng, 1986; Hyttel et al., 1986; Shabankareh et al., 2015). Recent evidence had revealed that certain genes like H2A, FSHR, GHR etc. were related to the oocytes competence. But $\mathrm{H} 2 \mathrm{~A}$ gene and the oocytes specific histone are essentially related to the size of the follicles. The oocytes recovered from $<6 \mathrm{~mm}$ sized follicles had lower levels of $\mathrm{H} 2 \mathrm{~A}$ transcripts and oocytes specific histone. Therefore, their developmental competence of the oocytes was compromised (Caixeta et al., 2009) and have the delayed cellular developmental stages of embryos (Lequarre et al., 2005). These are some most plausible reasons for greater in vitro developmental competence of the oocytes retrieved from follicles having size $\geq 6 \mathrm{~mm}$ in Bos taurus cows. Similar studies are warranted to elucidate the difference of cellular growth, 
cell cycles and genomic expression between the oocytes retrieved from large and small sized follicles in Bos indicus cows.

The results of the present study demonstrated that the recovery of oocytes was greater $(P<0.05)$ in $\geq 6 \mathrm{~mm}$ as compared to $<6 \mathrm{~mm}$ group, respectively. These results are supported by the previous studies in which the recovery rate was greater from the follicles having size $\geq 6 \mathrm{~mm}$ (Lonergan et al., 1994; Crozet et al., 1995). Likewise, the quality of grade I_ and _Il oocytes was about $26 \%$ superior for oocytes which were derived from $\geq 6 \mathrm{~mm}$ follicles as compared to $<6$ $\mathrm{mm}$ follicles. Equally, the percentage of good quality oocytes was greater in $\geq 6 \mathrm{~mm}$ group (Lonergan et al., 1994). Moreover, it has been reported that not only the size of follicle, but the diameter of the retrieved oocyte is also positively associated with the enhanced quality and in vitro developmental competence of oocytes. The oocytes recovered from larger follicles have greater diameter. Similarly, the oocytes having greater diameter $(>115 \mu \mathrm{m})$ maximally reach up to the MII and further developmental stages (Otoi et al., 1997).

Previously, it was reported that under in vivo conditions, the follicle deviation occurs at a size of 5.4 to $6.1 \mathrm{~mm}$ Bos indicus cows (Sartorelli et al., 2005; Castilho et al., 2007; Gimenes et al., 2008) and the diameter of the follicle from which ovulation occurred at the time of second GnRH of FTAl protocol influenced the synchronization of ovulation time and pregnancy per Al (P/AI) in cows (Perry et al., 2005). The presence of larger follicle on the day of FTAI improved ovulation rate and P/Al. However, the presence of $<7.5 \mathrm{~mm}$ follicles on the day of FTAl resulted in reduced ovulation and P/Al (Sá Filho et al., 2010). The most plausible reason is that during follicular growth and oocyte development, $\mathrm{mRNA}$ and proteins are produced and stored in the oocyte (Brevini-Gandolfi and Gandolfi, 2001) and developmental competence continues to increase with increased follicular diameter in cows (Arlotto et al., 1996). Similarly, for IVEP, the oocytes obtained from smaller follicles $(<6 \mathrm{~mm})$ have lower developmental competence due to incomplete nuclear and cytoplasmic maturation, greater degree of atresia (Pavlok et al., 1988), lack of production of essential proteins that are required for in vitro growth competence (Sirard et al., 1989). Therefore, it is plausible to suggest that for good quality oocytes and better outcome of IVEP $\geq 6 \mathrm{~mm}$ follicles should be aspirated. Therefore, future studies should be done to enhance the size of follicle $\geq 6 \mathrm{~mm}$ by using hormonal treatments like FSH and eCG prior to ovum pick up to enhance embryo production rates. And, on the addition of different hormones in IVM media for the oocytes derived from $<6 \mathrm{~mm}$ follicles.

On ovary, the mean number of $\geq 6 \mathrm{~mm}$ follicles was 3 times lower than that of $<6 \mathrm{~mm}$ follicles. The reason behind this is that, the Bos indicus cows have been reported to have smaller ovaries (Mutiga et al., 1993) and higher number of follicles having $<5 \mathrm{~mm}$ diameter (Fair et al., 1995; Baruselli et al., 2007; Caixeta et al., 2009) than Bos taurus cows. The antral follicle population is positively correlated with the plasma concentrations of anti mullerian hormone (AMH). The circulating concentration of AMH is greater in Bos indicus as compared to Bos taurus cows (Batista et al., 2014). Therefore, the population of follicles on ovaries is greater in Bos indicus (Fair et al., 1995; Baruselli et al., 2007) as compared to Bos taurus cows.

\section{Conclusion}

The competence of the oocytes was tested based on the ability of embryonic conversion. It was concluded that recovery rate of oocytes, cleavage rate, 4-cell, 8-cell, and 16-cell stage embryos were greater in the oocytes recovered from $\geq 6 \mathrm{~mm}$ as compared to $<6 \mathrm{~mm}$ follicles in Bos indicus cows. It is plausible to suggest that for IVEP $\geq 6 \mathrm{~mm}$ follicles should be preferred for aspiration in Bos indicus cows.

\section{Acknowledgements}

This research was financially supported by NRPU project of Higher Education Commission (HEC), Islamabad, Pakistan. The authors are gratified to PAMCO (Punjab Agriculture \& Meat Company) for the provision of ovaries from slaughtered animals. We gratefully acknowledge Dr. Naeem Iqbal, Head Section ART Lab/Sr. Clinical Scientist, King Faisal Specialist Hospital \& 
Research Center, Jeddah, Kingdom of Saudi Arabia for providing constant help throughout the in vitro trials.

\section{References}

Al-Katanani Y, Paula-Lopes F, Hansen P. Effect of season and exposure to heat stress on oocyte competence in holstein cows 1. J Dairy Sci. 2002;85(2):390-6. http://dx.doi.org/10.3168/jds.S00220302(02)74086-1. PMid:11913699.

Arlotto T, Schwartz JL, First NL, Leibfried-Rutledge ML. Aspects of follicle and oocyte stage that affect in vitro maturation and development of bovine oocytes. Theriogenology. 1996;45(5):943-56. http://dx.doi.org/10.1016/0093-691X(96)00024-6. PMid:16727855.

Armstrong D. Effects of maternal age on oocyte developmental competence. Theriogenology. 2001;55(6):1303-22. http://dx.doi.org/10.1016/S0093-691X(01)00484-8. PMid:11327686.

Baruselli P, Gimenes L, Sales JS. Fisiologia reprodutiva de fêmeas taurinas e zebuínas. Rev Bras Reprod Anim. 2007;31:205-11.

Batista E, Macedo G, Sala R, Ortolan MDDV, Sá Filho MF, Del Valle TA, Jesus EF, Lopes RN, Rennó FP, Baruselli PS. Plasma antimullerian hormone as a predictor of ovarian antral follicular population in Bos indicus (Nelore) and Bos taurus (Holstein) heifers. Reprod Domest Anim. 2014;49(3):448-52. http://dx.doi.org/10.1111/rda.12304. PMid:24689827.

Bó G, Baruselli P, Martınez M. Pattern and manipulation of follicular development in Bos indicus cattle. Anim Reprod Sci. 2003;78(3-4):307-26. http://dx.doi.org/10.1016/S0378-4320(03)00097-6. PMid:12818651.

Boediono A, Rajamahendran R, Saha S, Sumantri C, Suzuki T. Effect of the presence of a CL in the ovary on oocyte number, cleavage rate and blastocyst production in vitro in cattle. Theriogenology. 1995;1(1):169. http://dx.doi.org/10.1016/0093-691X(95)92323-2.

Brevini-Gandolfi TA, Gandolfi F. The maternal legacy to the embryo: cytoplasmic components and their effects on early development. Theriogenology. 2001;55(6):1255-76. http://dx.doi.org/10.1016/S0093691X(01)00481-2. PMid:11327683.

Caixeta ES, Ripamonte P, Franco MM, Junior JB, Dode MAN. Effect of follicle size on mRNA expression in cumulus cells and oocytes of Bos indicus: an approach to identify marker genes for developmental competence. Reprod Fertil Dev. 2009;21(5):655-64. http://dx.doi.org/10.1071/RD08201. PMid:19486602.

Camargo LS, Viana JHM, Sá WF, Ferreira AM, Ramos AA, Vale V Fo. Factors influencing in vitro embryo production. Anim Reprod. 2018;3:19-28.

Castilho C, Garcia JM, Renesto A, Nogueira GP, Brito LFC. Follicular dynamics and plasma FSH and progesterone concentrations during follicular deviation in the first post-ovulatory wave in Nelore (Bos indicus) heifers. Anim. Reprod. Sci. 2007; 98:189-96.

Chowdhury M, Lianguang X, Kong R, Park BY, Mesalam A, Joo MD, Afrin F, Jin JI, Lim HT, Kong IK. In vitro production of sex preselected cattle embryos using a monoclonal antibody raised against bull sperm epitopes. Anim Reprod Sci. 2019;205:156-64.

Cran D, Cheng WTK. The cortical reaction in pig oocytes during in vivo and in vitro fertilization. Gamete Res. 1986;13(3):241-51. http://dx.doi.org/10.1002/mrd.1120130307.

Crozet N, Ahmed-Ali M, Dubos M. Developmental competence of goat oocytes from follicles of different size categories following maturation, fertilization and culture in vitro. J Reprod Fertil. 1995;103(2):2938. http://dx.doi.org/10.1530/jrf.0.1030293. PMid:7616502.

Crozet N, Kanka J, Motlik J, Fulka J. Nucleolar fine structure and RNA synthesis in bovine oocytes from antral follicles. Mol Reprod Dev. 1986;14:65-73.

De Wit A, Wurth Y, Kruip TA. Effect of ovarian phase and follicle quality on morphology and developmental capacity of the bovine cumulus-oocyte complex. J Anim Sci. 2000;78(5):1277-83. http://dx.doi.org/10.2527/2000.7851277x. PMid:10834583.

Driancourt M. Follicular dynamics in sheep and cattle. Theriogenology. 1991;35(1):55-79. http://dx.doi.org/10.1016/0093-691X(91)90148-7.

Fair T, Hyttel P, Greve T. Bovine oocyte diameter in relation to maturational competence and transcriptional activity. Mol Reprod Dev. 1995;42(4):437-42.

http://dx.doi.org/10.1002/mrd.1080420410. PMid:8607973. 
Gasparrini B. In vitro embryo production in buffalo species: state of the art. Theriogenology. 2002;57(1):237-56. http://dx.doi.org/10.1016/S0093-691X(01)00669-0. PMid:11775973.

Gimenes LU, Sá Filho MF, Carvalho NA, Torres-Júnior JR, Souza AH, Madureira EH, Trinca LA, Sartorelli ES, Barros CM, Carvalho JB, Mapletoft RJ, Baruselli PS. Follicle deviation and ovulatory capacity in Bos indicus heifers. Theriogenology. 2008;69(7):852-8. http://dx.doi.org/10.1016/j.theriogenology.2008.01.001. PMid:18316116.

Glass EJ, Preston PM, Springbett A, Craigmile S, Kirvar E, Wilkie G, Brown CD. Bos taurus and Bos indicus (Sahiwal) calves respond differently to infection with Theileria annulata and produce markedly different levels of acute phase proteins. Int J Parasitol. 2005;35(3):337-47. http://dx.doi.org/10.1016/j.ijpara.2004.12.006. PMid:15722085.

Gordon I. Laboratory production of cattle embryos. Wallingford, UK: CABI; 2003. http://dx.doi.org/10.1079/9780851996660.0000.

Hendriksen P, Vos P, Steenweg W, Bevers M, Dieleman S. Bovine follicular development and its effect on the in vitro competence of oocytes. Theriogenology. 2000;53(1):11-20. http://dx.doi.org/10.1016/S0093-691X(99)00236-8. PMid:10735058.

Hyttel P, Xu K, Smith S, Greve T. Ultrastructure of in-vitro oocyte maturation in cattle. J Reprod Fertil. 1986;78(2):615-25. http://dx.doi.org/10.1530/jrf.0.0780615. PMid:3806520.

Kastrop P, Bevers M, Destree O, Kruip TA. Analysis of protein synthesis in morphologically classified bovine follicular oocytes before and after maturation in vitro. Mol Reprod Dev. 1990;26(3):222-6. http://dx.doi.org/10.1002/mrd.1080260305. PMid:2375875.

Khan MS, Rehman Z, Khan MA, Ahmad S. Genetic resources and diversity in Pakistani cattle. Pak Vet J. 2008;28:95-102.

Lequarre AS, Vigneron C, Ribaucour F, Holm P, Donnay I, Dalbiès-Tran R, Callesen H, Mermillod P. Influence of antral follicle size on oocyte characteristics and embryo development in the bovine. Theriogenology. 2005;63(3):841-59. http://dx.doi.org/10.1016/j.theriogenology.2004.05.015. PMid:15629802.

Lonergan P, Monaghan P, Rizos D, Boland M, Gordon I. Effect of follicle size on bovine oocyte quality and developmental competence following maturation, fertilization, and culture in vitro. Mol Reprod Dev. 1994;37(1):48-53. http://dx.doi.org/10.1002/mrd.1080370107. PMid:8129930.

Montalenti G. ASDELL, SA-Patterns of Mammalian Reproduction. Ithaca, NY: Cornell University Press; 1968.

Moore S, Hasler J. A 100-year review: Reproductive technologies in dairy science. J Dairy Sci. 2017;100(12):10314-31. http://dx.doi.org/10.3168/jds.2017-13138. PMid:29153167.

Mutiga E, Mukasa-Mugerwa E, Azage T. Luteolytic effect of prostaglandin F 2a in Boran and Boranx Friesian cross-bred heifers. J Agric Sci. 1993;120(1):103-6. http://dx.doi.org/10.1017/S0021859600073652.

Otoi T, Yamamoto K, Koyama N, Tachikawa S, Suzuki T. Bovine oocyte diameter in relation to developmental competence. Theriogenology. 1997;48(5):769-74. http://dx.doi.org/10.1016/S0093691X(97)00300-2. PMid:16728170.

Parrish J, Krogenaes A, Susko-Parrish J. Effect of bovine sperm separation by either swim-up or Percoll method on success of in vitro fertilization and early embryonic development. Theriogenology. 1995;44(6):859-69. http://dx.doi.org/10.1016/0093-691X(95)00271-9. PMid:16727781.

Pavlok A, Lucas-Hahn A, Niemann H. Fertilization and developmental competence of bovine oocytes derived from different categories of antral follicles. Mol Reprod Dev. 1992;31(1):63-7. http://dx.doi.org/10.1002/mrd.1080310111. PMid:1562328.

Pavlok A, Torner H, Motlik J, Fulka J, Kauffold P, Duschinski U. Fertilization of bovine oocytes in vitro: effect of different sources of gametes on fertilization rate and frequency of fertilization anomalies. Anim Reprod Sci. 1988;16(3-4):207-13. http://dx.doi.org/10.1016/0378-4320(88)90014-0.

Perry GA, Smith MF, Lucy MC, Green JA, Parks TE, Macneil MD, Roberts AJ, Geary TW. Relationship between follicle size at insemination and pregnancy success. Proc Natl Acad Sci USA. 2005;102(14):5268-527. http://dx.doi.org/10.1073/pnas.0501700102. PMid:15795381.

Rose TA, Bavister BD. Effect of oocyte maturation medium on in vitro development of in vitro fertilized bovine embryos. Mol Reprod Dev. 1992;31(1):72-7. http://dx.doi.org/10.1002/mrd.1080310113. PMid:1562330. 
Sá Filho MF, Crespilho AM, Santos JEP, Perry GA, Baruselli PS. Ovarian follicle diameter at timed insemination and estrous response influence likelihood of ovulation and pregnancy after estrous synchronization with progesterone or progestin-based protocols in suckled Bos indicus cows. Anim Reprod Sci. 2010;120(1-4):23-30. http://dx.doi.org/10.1016/j.anireprosci.2010.03.007. PMid:20395079.

Saad M, Sarwar Z, Saleem M, Arshad U, Shahzad M, Hassan Mushtaq M, Husnain A, Riaz A, Ahmad N. Effect of plasma progesterone on oocyte recovery, oocyte quality, and early in-vitro developmental competence of embryos in Bos indicus dairy cows. Anim Reprod Sci. 2019;202:80-6. http://dx.doi.org/10.1016/j.anireprosci.2019.02.001. PMid:30765111.

Sartorelli ES, Carvalho LM, Bergfelt DR, Ginther OJ, Barros CM. Morphological characterization of follicle deviation in Nelore (Bos indicus) heifers and cows. Theriogenology. 2005;63(9):2382-94. http://dx.doi.org/10.1016/j.theriogenology.2004.08.017. PMid:15910921.

Sartori R, Bastos M, Baruselli P, Gimenes L, Ereno R, Barros C. Physiological differences and implications to reproductive management of Bos taurus and Bos indicus cattle in a tropical environment. Soc Reprod Fertility Suppl. 2010;67:357-75.

Shabankareh HK, Shahsavari MH, Hajarian H, Moghaddam G. In vitro developmental competence of bovine oocytes: effect of corpus luteum and follicle size. Iran J Reprod Med. 2015;13(10):615-22. PMid:26644789.

Sirard M, Florman H, Leibfried-Rutledge M, Barnes F, Sims M, First N. Timing of nuclear progression and protein synthesis necessary for meiotic maturation of bovne oocytes. Biol Reprod. 1989;40(6):125763. http://dx.doi.org/10.1095/biolreprod40.6.1257. PMid:2775818.

Snijders S, Dillon P, O'Callaghan D, Boland M. Effect of genetic merit, milk yield, body condition and lactation number on in vitro oocyte development in dairy cows. Theriogenology. 2000b;53(4):981-9. http://dx.doi.org/10.1016/S0093-691X(00)00244-2. PMid:10730984.

Snijders SE, Dillon P, O'Callaghan D, Boland M. Effect of genetic merit, milk yield, body condition and lactation number on in vitro oocyte development in dairy cows. Theriogenology. 2000a;53(4):981-9. http://dx.doi.org/10.1016/S0093-691X(00)00244-2. PMid:10730984.

Thompson JG. Comparison of $I n$-vivo-derived and in-vitro-produced pre-elongation embryos from domestic ruminants. J Reprod Fertil. 1997;9(3):314-54. http://dx.doi.org/10.1071/r96079. PMid:9261882.

\section{Author contributions}

ZS: Conceptualization, Data curation, Investigation, Methodology, Resources, Validation, Writing- Original draft preparation; MS: Data curation, Investigation, Methodology, Resources, Validation, Writing- Original draft preparation; MS: Investigation, Methodology, Resources, Validation; AH: Data curation, Investigation, Statistical analysis, Writing-Review \& Editing; AR: Supervision, Writing-Review \& Editing; NA: Conceptualization, Project Administration, Supervision, Writing-Review \& Editing. 